\title{
43. SUMMARY OF GENERAL FEATURES OF ARABIAN SEA AND RED SEA CENOZOIC HISTORY BASED ON LEG 23 CORES
}

\author{
Robert B. Whitmarsh, National Institute of Oceanography, Wormley, Surrey, United Kingdom
}

\section{INTRODUCTION}

Almost all the sites drilled in the Arabian Sea (Table 1, Figure 1) sampled sediments representing most of Cenozoic time. Thus, it is possible to discuss the results of this part of Leg 23 of the Deep Sea Drilling Project in terms of the development of a normal ocean basin formed largely by, and subject to, processes of sea floor spreading. The Red Sea sites on the other hand (Table 2, Figure 1) sampled only the last 5 m.y. of the geological record, and the results from these cores pertain to the rather special processes (evaporite formation, initiation of oceanic crust) associated with the break-up of continental crust by sea floor spreading. Therefore, in making comparisons between the sites drilled on Leg 23, the discussion is divided into two sections treating the Arabian Sea and Red Sea sites separately.

\section{SOME GENERAL FEATURES OF THE ARABIAN SEA}

\section{Stratigraphy}

Figure 2 has been drawn as a basis for discussion. Unlike normal borehole stratigraphic sections, time has been used as the vertical axis. Thus, the figure illustrates the distribution in time of the sediments at the various sites. Further, the lithologies encountered in the cores have been assigned to a simple classification of biogenic carbonate, silts, clays, and unfossiliferous brown clays, and permutations of the first three, so that the time distribution of the major sediment facies is easy to comprehend. Although the figure is interpretive, it is based on the sedimentation rate charts (see Chapters 3 to 8 ) which were drawn according to a set of strict rules as explained in Chapter 2 . For example, those columns bounded on the right by a thick black line cannot possibly contain stratigraphic unconformities normally detectable by biostratigraphy, i.e., any periods of nondeposition must have lasted for a shorter time than the zone in which the sediments are found. On the other hand, biostratigraphic control is such that unconformities may exist in the remaining parts of the figure. The actual breaks in deposition which are illustrated are those indicated on the various sedimentation rate diagrams.

Although there are considerable periods of geologic time over which stratigraphic control is imperfect, the number of definite breaks in deposition is small: some 11 in all, averaging $3.3 \mathrm{~m} . y$. each, excluding those attributable to slumping. All these breaks, except three (15.5 m.y. at Site 219, 48 m.y. at Site 223, 50 m.y. at Site 224), could, because of the imperfect control, be present, at least in part, at all the other sites. If true, it would mean that the Late Paleocene, the Eocene, and the Late Miocene were periods of generally intermittent sedimentation. Conversely, it could be argued that the sites with the pre-Oligocene unconformities (Sites 219, 223, and 224) may have occupied elevated or exposed positions on ridges at that time and were thus more likely to be subject to strong bottom currents, which could cause nondeposition.

TABLE 1

Leg 23-Holes in the Arabian Sea

\begin{tabular}{lllllrrrrr}
\hline Hole & Dates (1972) & Latitude & Longitude & $\begin{array}{c}\text { Wepth } \\
(\mathrm{m})\end{array}$ & $\begin{array}{c}\text { Penetration } \\
(\mathrm{m})\end{array}$ & $\begin{array}{l}\text { No. of } \\
\text { Cores }\end{array}$ & $\begin{array}{l}\text { Cored } \\
(\mathrm{m})\end{array}$ & $\begin{array}{c}\text { Recovered } \\
(\mathrm{m})\end{array}$ & $\begin{array}{c}\text { Oldest } \\
\text { Sediments }\end{array}$ \\
\hline 219 & March 10-12 & $09^{\circ} 01.75^{\prime} \mathrm{N}$ & $72^{\circ} 52.67^{\prime} \mathrm{E}$ & 1,764 & 273 & 28 & 235 & 172.5 & \\
$219 \mathrm{~A}$ & March 12-13 & $09^{\circ} 01.75^{\prime} \mathrm{N}$ & $72^{\circ} 52.67^{\prime} \mathrm{E}$ & 1,764 & 411 & 14 & 115 & 50.6 & Late Paleocene \\
220 & March 14-17 & $06^{\circ} 30.97^{\prime} \mathrm{N}$ & $70^{\circ} 59.02^{\prime} \mathrm{E}$ & 4,036 & 350 & 21 & 177 & 100.9 & Early Eocene \\
221 & March 18-20 & $07^{\circ} 58.18^{\prime} \mathrm{N}$ & $68^{\circ} 24.37^{\prime} \mathrm{E}$ & 4,650 & 270 & 19 & 170 & 76.6 & Middle Eocene \\
222 & March 24-30 & $20^{\circ} 05.49^{\prime} \mathrm{N}$ & $61^{\circ} 30.56^{\prime} \mathrm{E}$ & 3,546 & 1,300 & 36 & 313 & 175.6 & Late Miocene \\
223 & Mar. 31/April 4 & $18^{\circ} 44.98^{\prime} \mathrm{N}$ & $60^{\circ} 07.78^{\prime} \mathrm{E}$ & 3,633 & 740 & 41 & 369 & 203.7 & Late Paleocene \\
224 & April 5-7 & $16^{\circ} 32.51^{\prime} \mathrm{N}$ & $59^{\circ} 42.10^{\prime} \mathrm{E}$ & 2,500 & 792 & 11 & 99 & 30.9 & Early Eocene \\
\hline
\end{tabular}

TABLE 2

Leg 23-Holes in the Red Sea

\begin{tabular}{|c|c|c|c|c|c|c|c|c|c|}
\hline Hole & Dates (1972) & Latitude & Longitude & $\begin{array}{c}\text { Water } \\
\text { Depth } \\
\text { (m) }\end{array}$ & $\begin{array}{l}\text { Penetration } \\
\text { (m) }\end{array}$ & $\begin{array}{l}\text { No. of } \\
\text { Cores }\end{array}$ & $\begin{array}{c}\text { Cored } \\
(\mathrm{m})\end{array}$ & $\begin{array}{l}\text { Recovered } \\
\text { (m) }\end{array}$ & $\begin{array}{c}\text { Oldest } \\
\text { Sediments }\end{array}$ \\
\hline 225 & April $15-17$ & $21^{\circ} 18.58^{\prime} \mathrm{N}$ & $38^{\circ} 15.11^{\prime} \mathrm{E}$ & 1,228 & 230 & 29 & 230 & 137.5 & Late Miocene \\
\hline 226 & April 17-18 & $21^{\circ} 20.51^{\prime} \mathrm{N}$ & $38^{\circ} 04.93^{\prime} \mathrm{E}$ & 2,169 & 14 & 2 & 14 & 8.9 & Late Quaternary \\
\hline 227 & April 18-21 & $21^{\circ} 19.86^{\prime} \mathrm{N}$ & $38^{\circ} 07.97^{\prime} \mathrm{E}$ & 1,795 & 350 & 45 & 344 & 123.5 & Late Miocene \\
\hline 228 & April 22-24 & $19^{\circ} 05.16^{\prime} \mathrm{N}$ & $39^{\circ} 00.20^{\prime} \mathrm{E}$ & 1,038 & 325 & 40 & 315 & 184.7 & Late Miocene? \\
\hline 229 & April 27-28 & $14^{\circ} 46.09^{\prime} \mathrm{N}$ & $42^{\circ} 11.47^{\prime} \mathrm{E}$ & 852 & 212 & 23 & 195 & 148.1 & Late Pleistocene \\
\hline 230 & April 28-29 & $15^{\circ} 19.00^{\prime} \mathrm{N}$ & $41^{\circ} 50.05^{\prime} \mathrm{E}$ & 832 & 9 & 2 & 18 & 13.4 & Late Pleistocene \\
\hline
\end{tabular}



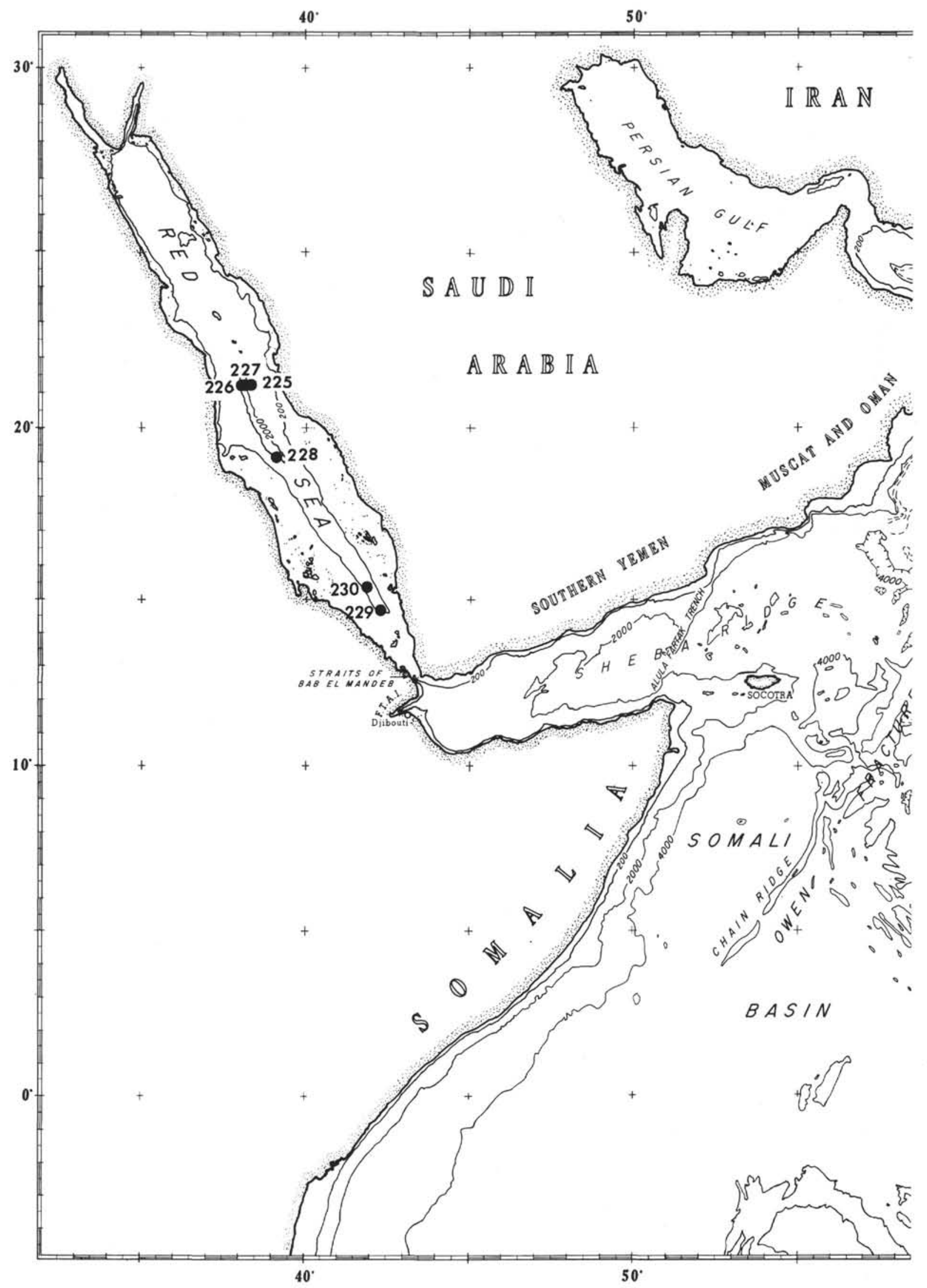

Figure 1. Position of Leg 23 sites in the Arabian Sea and Red Sea. 


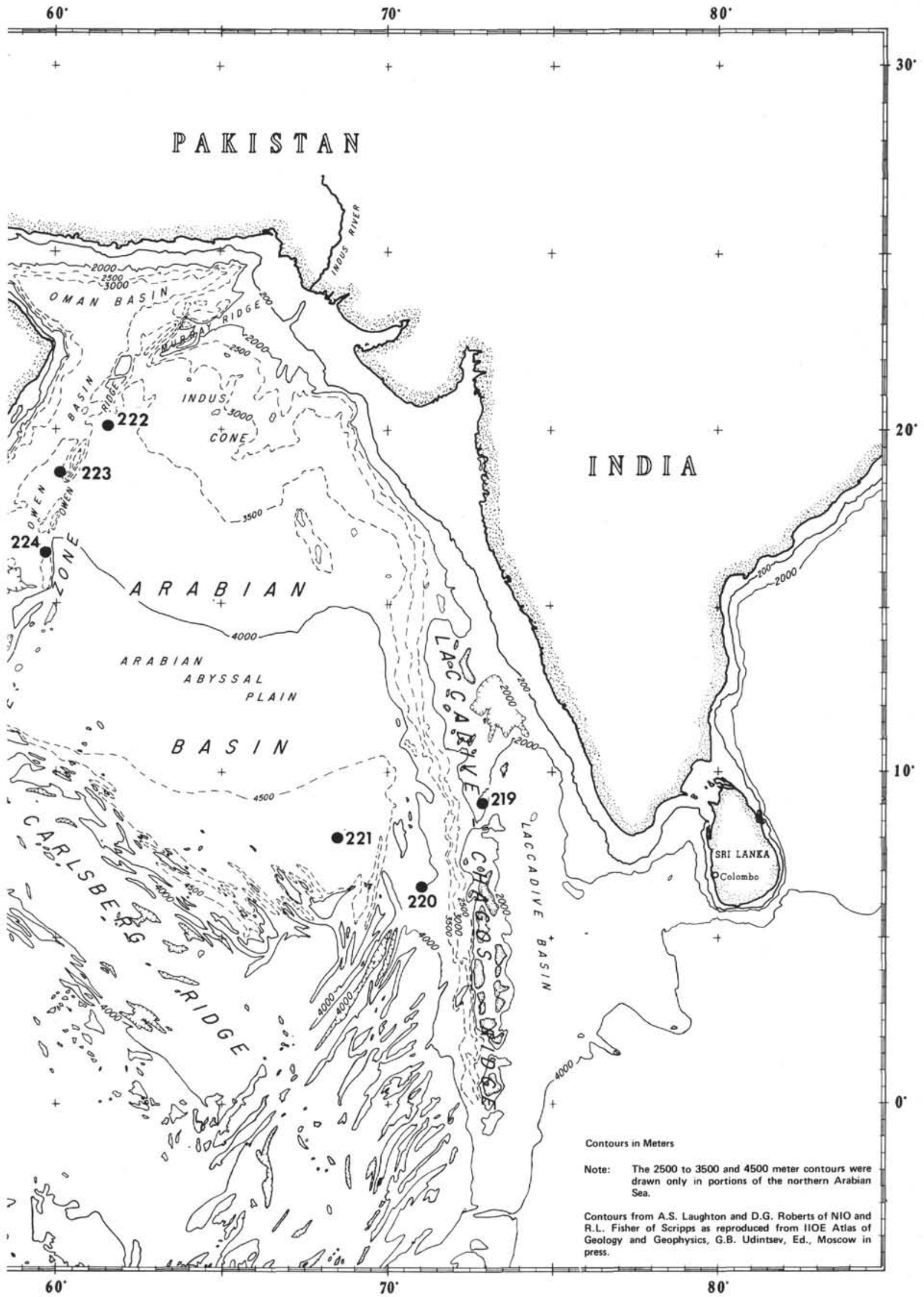

Figure 1. Continued 


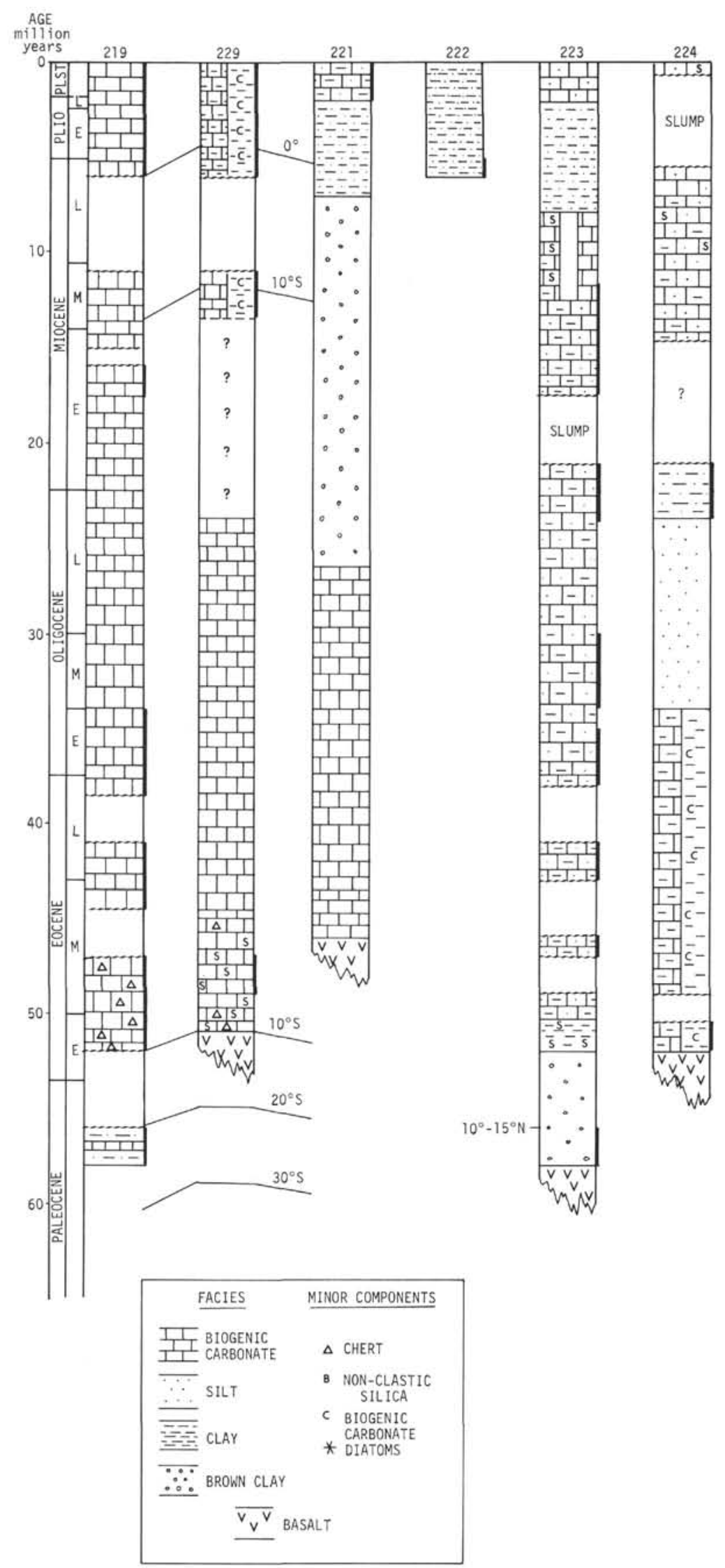

Figure 2. Stratigraphic columns for Sites 219 to 224 plotted with time as the vertical axis. See text for explanation. 
Although the Cenozoic sedimentary record is apparently quite continuous, the mean rates of sediment accumulation have fluctuated between 2 and $600 \mathrm{~m} / \mathrm{m} . \mathrm{y}$. At any one site, however, the minimum and maximum rates do not differ by a factor of more than 35 . When the sedimentation rate plots for each site are compared (Figure 3), a general tendency for the curves to have a sigmoidal shape with points of inflection in the Miocene and in the early Eocene is apparent. In other words, the rate of sedimentation from the early Eocene to the Miocene was markedly less than for the rest of Cenozoic time. It should also be mentioned that none of the rates in Figure 3 has been corrected for the effect of compaction. The greatest error will be in the rates for the deepest (oldest) intervals, but even so this probably does not exceed 30 per cent (see Chapters 5, 6, 8, 9, and 10 of Laughton et al., 1972).

One of the most obvious features common to the sediments at the Arabian Sea sites is the presence of chert and biogenic or authigenic silica in the Early and Middle Eocene. Although chert is found only in the cores of the southern Arabian Sea sites, it is present on land in Dhufar and Socotra. Clearly, therefore, the importance of nondetrital silica in these sediments is not due simply to the proximity of an equatorial zone of high productivity since Sites 223 and 224 were only slightly south of their present latitudes at the time. Instead, it is due to a more widespread effect which stimulated greater production and/or preservation of biogenic silica.

A further, near synchronous, effect appears to have been the onset of upwelling at Sites 223 and 224 in the late Middle Miocene. This was probably caused by establishment of the contemporary monsoon system which has already been discussed in Chapters 7 and 8 .

\section{Horizontal Motion of the Sea Floor}

Paleomagnetic measurements on samples from the cores (Whitmarsh et al., this volume) indicate that, since the Late Cretaceous, the Indian plate underwent two periods when there was a component of rapid northward movement. As indicated on Figure 2, there has apparently been little change in paleolatitude for much of Cenozoic time, however. From the Middle Eocene to the Middle Miocene, the sites in the southern Arabian Sea were near $10^{\circ} \mathrm{S}$ and only crossed the equator about 5 m.y. ago. Sites 223 and 224, situated west of the Owen Fracture Zone, have probably experienced only a few degrees of latitudinal movement throughout Cenozoic time.

Analyses of magnetic anomaly profiles produced by sea floor spreading currently suggest that there have been three phases of spreading in the Arabian Sea (Whitmarsh, this volume) with a hiatus in spreading beginning after about 46 m.y. B.P. (Middle Eocene). The end of the hiatus is poorly determined, but the results from Site 238 (Fisher et al., 1972) and other data of McKenzie and Sclater (1971) suggest it ended about 30 m.y. ago. These data are compared with the paleomagnetic results in Figure 4. All rates are measured in a northerly direction except for the most recent sea floor spreading rate, which is in a direction $040^{\circ}$. Two features of Figure 4 are immediately apparent; the northward drift of India is of an order of magnitude greater than its rate of movement away from the Carlsberg Ridge, and the hiatus in spreading appears to have lasted for a much shorter time than the halt in the northward drift of India. One is drawn to the conclusion, therefore, that the spreading axis between the Indian and African (Madagascan) plates had a strong component of northward motion before $50 \mathrm{~m} . y$. ago and for the last $20 \mathrm{~m} . \mathrm{y}$. This conclusion is not unexpected in light of the discussion by Francheteau and Sclater (1970) concerning comparisons of paleomagnetic and plate tectonic data.

\section{Vertical Motions of the Sea Floor}

The nature of the sediments can only indicate, at best, the water depth in which they were laid down, and, generally, can not indicate the sinking history of the subsiding basement on which they lie. The latter can only be deduced in special cases, as for instance from the thickness of accumulated sediments when the sea bed was close to sea-level, e.g., as at Site 219 , and when the subsidence of the basement exceeds the sedimentation rate. Bearing this constraint in mind, it is possible to discuss several instances of vertical tectonics at the Arabian Sea sites.

The basement of Site 219 appears to have sunk about 2100 meters since the Late Paleocene, but there is currently no information available which suggests when, or if, the sinking ceased. The presence of coral atolls along the Laccadive-Maldive Ridge is believed to indicate that the foundation of these islands has also sunk, presumably contemporaneously with Site 219 .

Sites 223 and 224 were uplifted in the Early Miocene. The uniformity of thickness of the tilted layers on the seismic reflection profile across Site 223 suggests uplift of about 1000 meters at this site. At Site 224, turbidites were cored at 2950 meters, well above the level of the two adjacent abyssal plains today. These turbidites are in the vicinity of a dipping reflector which can be traced to a depth of about 4100 meters to the west, suggesting uplift of at least 1150 meters at this site.

The sinking of normal oceanic basement, due to lithospheric cooling, is expected to influence the overlying sedimentary sequence provided the rate of subsidence exceeded deposition, as has been demonstrated in the Pacific by Heezen et al. (1973). Unfortunately, this effect cannot yet be convincingly demonstrated by the cores from the small number of suitable sites (only 220,221, and 222 lay over normal ocean crust) in the Arabian Sea. An unfossiliferous brown clay was cored at Site 221, however, which lies above nanno ooze. This appears to be a good example of where initial calcareous ooze deposition was replaced by brown clay sediments as the sea bed sank (and spread). Further detailed studies of benthic foraminifera and of the solution of the tests of planktonic foraminifera may serve to demonstrate approximately the systematic changes in ocean basement depth that are expected from sea floor spreading. Only when the pattern of lithologies attributable to this process is understood will it be possible to determine what changes, if any, have occurred in the calcium carbonate compensation depth (see also, Weser, this volume). 
R. WHITMARSH
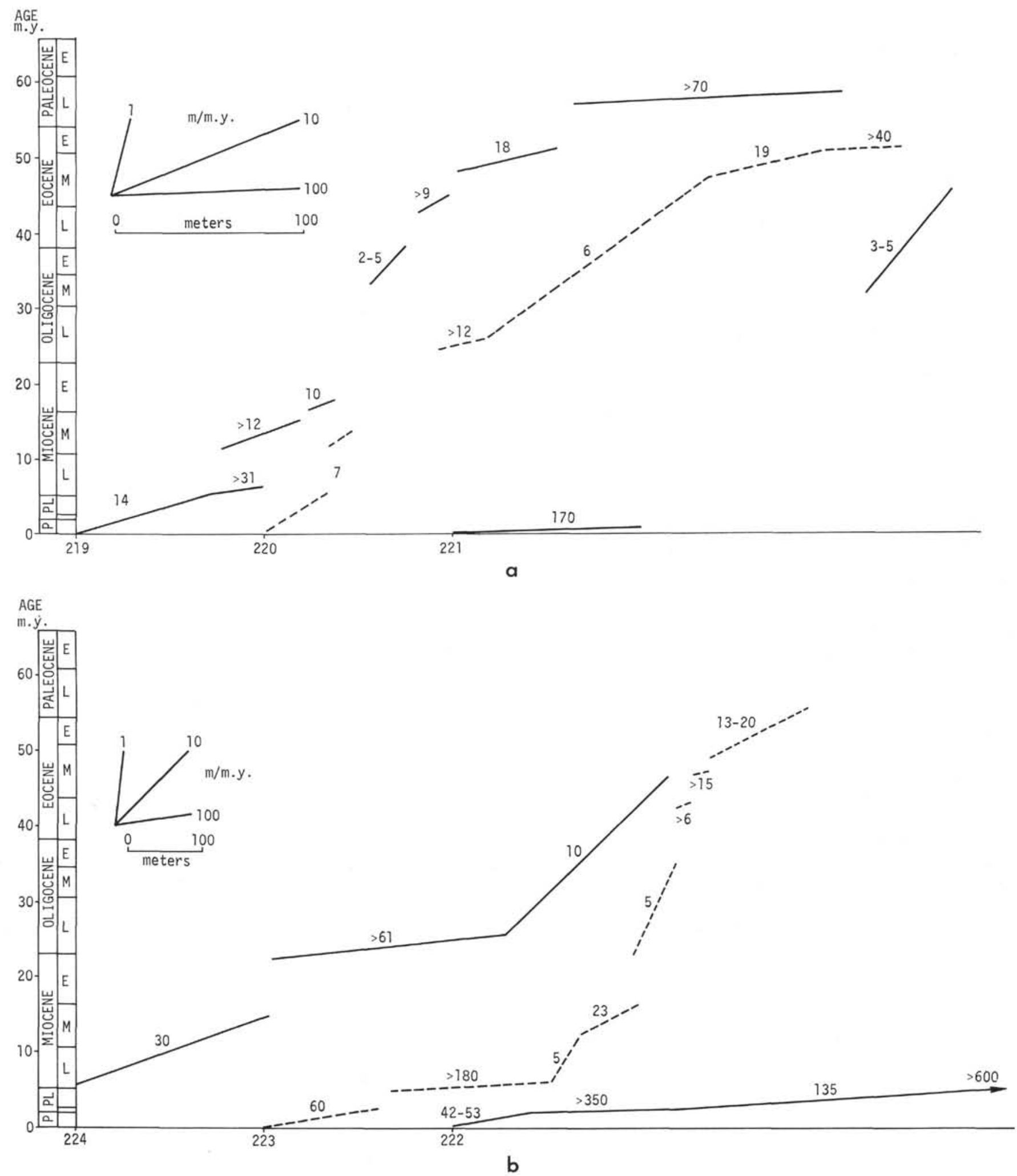

Figure 3. Sedimentation rate curves for Arabian Sea sites. The curves have been offset from each other along the depth axis for clarity. (a) Sites 219, 220, 221 (b) Sites 222, 223, 224. 


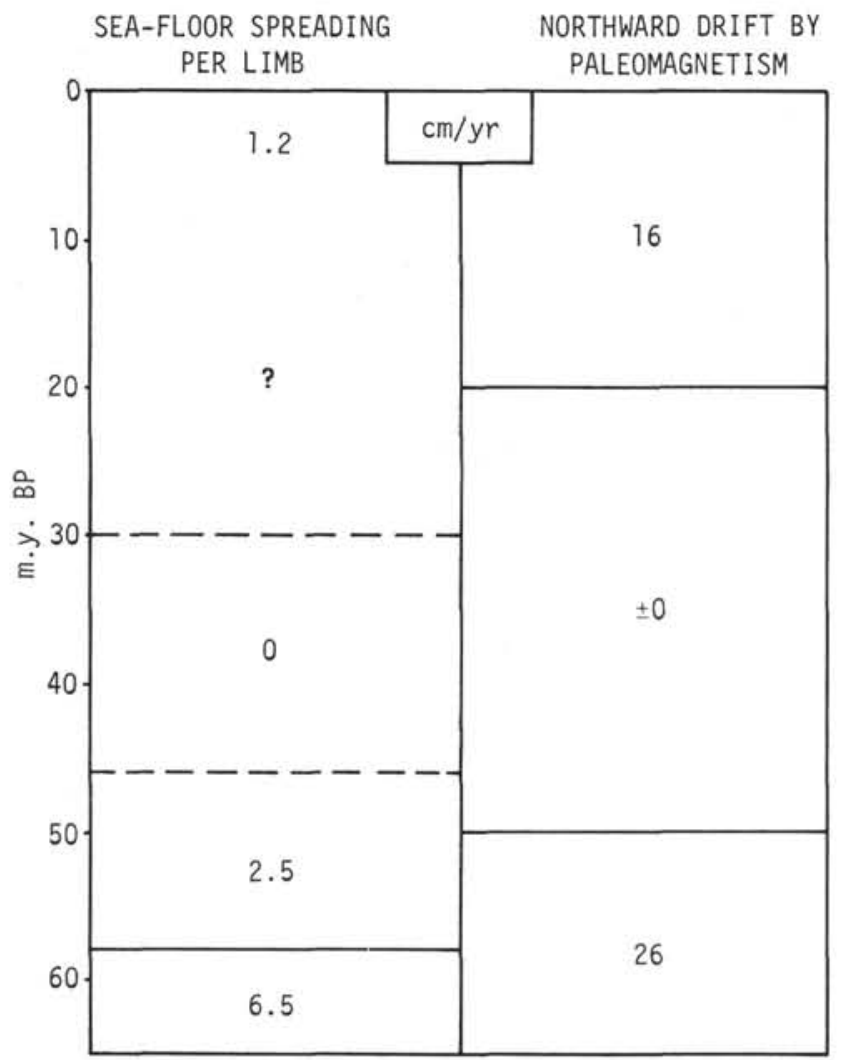

Figure 4. Comparison of the Cenozoic spreading history and history of northward drift of the Indian plate.

\section{Important Episodes in Arabian Sea History}

In reviewing the data of Figure 2 and comparing this figure with other well-determined and relevant geological events, some of which occurred in the surrounding continents, it is apparent that two periods of Cenozoic history, the Middle Eocene and early Miocene, were particularly important in the development of the Arabian Sea.

Near the beginning of the Middle Eocene, the northward drift of India ceased and the Himalayas underwent their first major uplift (Wadia, 1966). Since these mountains mark the boundary between the colliding Indian and Eurasian plates, it is likely that these two events are connected. Further, but possibly coincidentally, the Paleogene phase of sea floor spreading ceased towards the end of the Middle Eocene. This period was also marked by changes in the sediments. It was in the Middle Eocene that the important contribution of biogenic silica came to an end, especially at the southern Arabian Sea sites. Lastly, the Middle Eocene, particularly at Sites 219, 220, and 223, appears to have been a time when mean sedimentation rates began to decrease markedly (Figure 3 ). The disappearance of biogenous silica and the reduction in sedimentation rate are probably attributable to a major change in ocean circulation at this time, but a fuller explanation is not attempted here.

The second important period appears to have been the Early Miocene. This again was characterized by major tectonic events. Paleomagnetic results (Whitmarsh et al., this volume) suggest that the northward drift of India resumed in the Early Miocene. Also, according to Laughton et al. (1970), with whom the results of Site 231 (Fisher et al., 1972) are not inconsistent, the Gulf of Aden began to open. Concurrently, Sites 223 and 224, adjacent to the Owen Ridge, were uplifted. Vertical tectonics also affected the Oman Mountains, and there was a major regression in peninsular India. Slightly later in the Middle Miocene, the second major phase of Himalalayan uplift began, and at the same time, and probably as a consequence, monsoonal upwelling appears to have begun off the SE coast of Arabia and possibly off the Maldives. Due to the lack of a distinctive pattern in the reversal time scale in this part of the Neogene, no anomaly identifications have been made in the Gulf of Aden or Arabian Sea. Thus, it is not known whether or not there were any important changes in spreading rate at this time.

\section{Summary of Results}

The main results of the Leg 23 drilling by Glomar Challenger in the Arabian Sea are summarized below. Brief versions of the results and history of each site can also be found in the abstract (first page) and depositional history (last section) sections of the site chapters (Chapters 3 to 8).

1) Site 219 was drilled on the Laccadive-Chagos Ridge in an attempt to reach igneous basement so as to test the fracture zone and hot spot origins proposed for this feature.

AGE

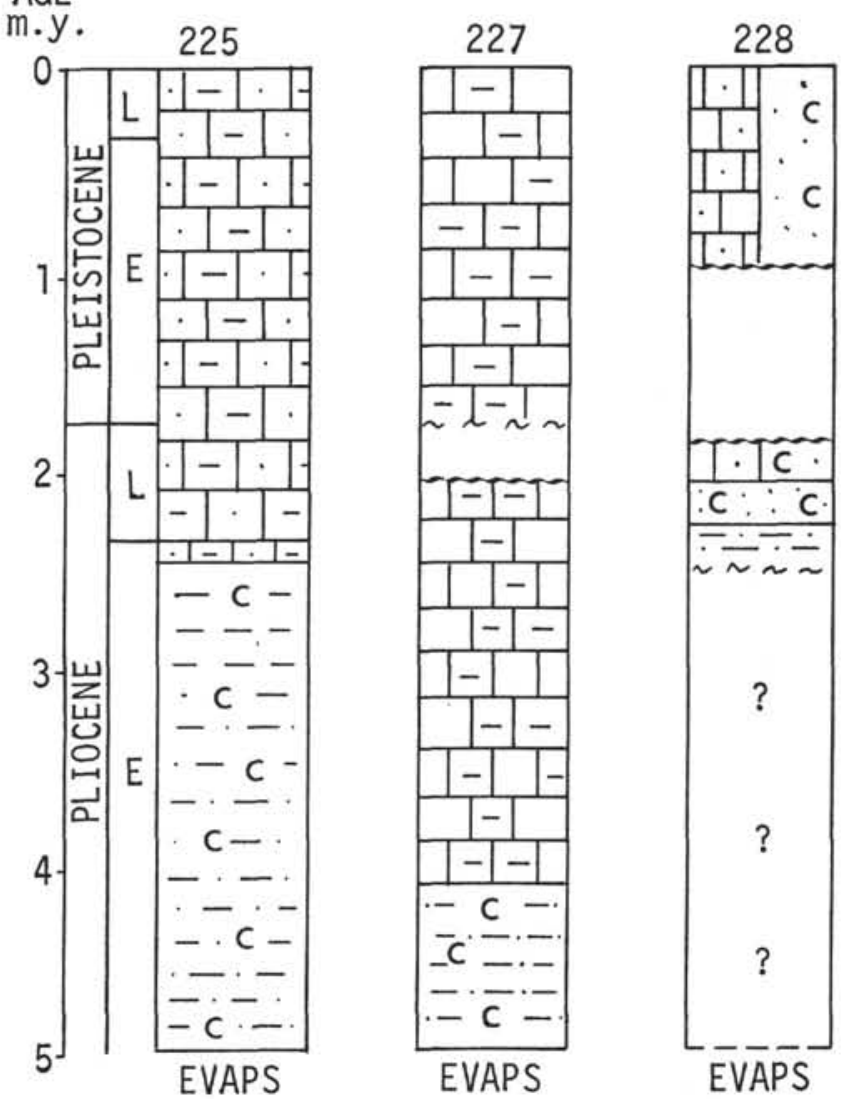

Figure 5. Stratigraphic columns for Sites 225, 227, and 228 plotted with time as the vertical axis. 
Although basement was not reached, the evidence from this site is not inconsistent with the hot spot origin. This hypothesis is favored on the basis of independent bathymetric, seismic profiler, and absolute age data, which seem to rule out the fracture zone explanation (Whitmarsh, this volume).

2) A widespread lower Middle Eocene chert reflector was found in the southeast Arabian Sea. This reflector probably extends northwards at depth beneath the Arabian Abyssal Plain and probably accounts for the strong deep reflector found there by Neprochnov (1961).

3) The magnetic anomaly profiles obtained by Glomar Challenger and other ships in the southeast Arabian Sea together with the definite paleontological ages assigned to the basal sediments at Sites 220 and 221 have led to further understanding of the sea floor spreading history of this region. New Paleogene fracture zones have been found, and evidence of continuous spreading up to at least 46 m.y.B.P. is adduced (Whitmarsh, this volume).

4) Paleomagnetic studies of the Glomar Challenger cores have greatly extended the range of observations describing the northward drift of India in the Cenozoic, which has now been shown to have occurred in two stages (Whitmarsh et al., this volume). It has also been demonstrated that sites west of the Owen Fracture Zone have had almost constant paleolatitude, thus confirming that important shear took place across this fault.

5) The results from Sites 221 and 222 have led to a greater understanding of the origin and depositional mechanisms of sediments in the Arabian Abyssal Plain. At Site 221, sediments originating from both the west Indian shelf and the Indus Canyon were cored. The Indus Cone sediments of Site 222 appear to have been transported by several mechanisms, including turbidity currents and slower-speed suspension currents (Jipa and Kidd, this volume).

6) It was demonstrated by the track between Sites 223 and 224 that the Owen Ridge is almost certainly a continuous feature along the west side of the Owen Fracture Zone for some $900 \mathrm{~km}$. This has important implications for the Cenozoic sedimentary history of the flanking basins since the ridge has probably acted as a barrier to near bottom transported sediments throughout much of this time. It was also discovered that the ridge was tilted and probably uplifted at some time in the Early Miocene. The ridge appears to have an unusual igneous petrology; both trachybasalt and lamprophyre were cored.

7) An unexpected result was the discovery off the southeast coast of Arabia, where upwelling occurs today during the SW Monsoon, of firm evidence of upwelling beginning in the Middle Miocene sediments of Site 223. More fragmentary evidence of upwelling beginning at the same time was discovered at Sites 219 and 224.

\section{THE IMPLICATIONS OF LEG 23 RESULTS FOR THE HISTORY OF THE RED.SEA}

\section{Stratigraphy \\ Sediments of Late Miocene age were reached at three of the sites occupied in the Red Sea, but at the remaining}

sites, either penetration was so short (Sites 226, 230) or the sedimentation rate so high (Site 229) that sediments no older than Late Pleistocene were cored. The former three sites, however, are very similar in lithology and stratigraphy. A summary log for these sites, plotted with time as the vertical axis, is presented in Figure 5. The similarity of the sites can be seen in this figure. The missing section at Site 228 is due to salt diapirism. The apparent unconformity seen at Sites 227 and 228 may also exist at Site 225 , where the biostratigraphic control is poor. The basic sequence of silty or clayey nanno ooze, claystone, and evaporites (anhydrite and salt) is repeated at each site. The sedimentation rates at these three sites are fairly constant, averaging about $100 \mathrm{~m} / \mathrm{m} . y$. at Sites 225 and 227 but being somewhat higher at Site 228 .

\section{Spreading History}

It is widely recognized that the axial trough of the Red Sea is the locus of active sea floor spreading. Not only is the trough a thinly sedimented region with fresh lavas cropping out on the sea floor, but, also, it marks the center of a suite of linear magnetic anomalies which can be simulated by a sea floor spreading model moving at about $0.9 \mathrm{~cm} / \mathrm{yr} / \mathrm{limb}$ for, conservatively, the last $2.4 \mathrm{~m} . \mathrm{y}$. High heat flow is characteristic of the whole width of the Red Sea, although even higher values occur near the center, and this situation was confirmed by downhole measurements made during Leg 23 (Girdler et al., this volume). The outstanding problem of the Red Sea is whether there was a period of sea floor spreading before $2.4 \mathrm{~m} . y$. ago, either continuous with the present phase or separated from it by a hiatus, or whether the remaining width of the Red Sea, outside the strip formed in the last 2.4 m.y., is underlain by crust not formed by such a process but possibly by sunken continental crust (Coleman, this volume; Girdler and Whitmarsh, this volume). To solve this problem by drilling requires holes which penetrate the probably 2 - to 4-km-thick evaporite sequence; this was outside the capabilities of Glomar Challenger. However, an interesting enigma was presented by the discovery of $5 \mathrm{~m} . \mathrm{y}$. old Late Miocene evaporites within the 0 to $2.4 \mathrm{~m} . \mathrm{y}$. old strip centered on the axial trough. This has been explained to the satisfaction of a minority of the shipboard scientists as being the result of post-Miocene lateral salt flowage (Girdler and Whitmarsh, this volume).

Site 229 in the southern Red Sea had been especially selected to test whether the axial trough extended southwards beneath thick sediments south of Zebayir Island. The results from this site, although not conclusive suggest this is the case; in particular the pore-water salinities do not indicate the presence of halite beneath the site.

\section{Miocene Evaporites}

The recent speculation concerning the origin of Miocene evaporites cored by Glomar Challenger in the Mediterranean (Ryan et al., 1973) has added extra incentive to studies of the far greater amount of evaporite material recovered in Leg 23 cores. Before discussing the conditions of formation of the Red Sea evaporites, brief mention should be made of the extent of these beds. One of the major objectives of drilling in the Red Sea was to establish 
in several places the nature of a strong and widespread reflector found up to 500 meters below the sea bed. This reflector, named $S$, seems to be found everywhere but in the axial trough. The Leg 23 cores demonstrated that this feature essentially marks the top of the Miocene evaporite sequence and, therefore, the evaporites too are believed to exist under almost the whole Red Sea, even, it appears, in blocks or slump features on the flanks of the axial trough (Site 230).

Only at Site 227 were fossiliferous beds found within the evaporitic strata and, on the basis of the nanno flora, they were shown to belong to the Late Miocene Discoaster quinqueramus Zone. The evaporites have been studied petrographically by Stoffers and Kühn (this volume). These authors conclude that although there are definite signs of shallow-water formation, these do not unequivocably rule out occasional periods of deep water when the Red Sea basin was almost full. They also caution that it is not certain that the total evaporite sequence of the Red Sea, several kilometers thick, formed by the same processes that were responsible for the top 135 meters sampled during Leg 23. Foraminiferal faunas indicate that at the close of the Micoene, the Red Sea had access to the Indian Ocean. The extremely rare Mediterranean forms in the Leg 23 cores indicate that any connections with that sea in post-Miocene time were short lived.

\section{Heavy Metal Enriched Sediments}

The prime objective in the Red Sea was to find the thickness and extent of the heavy metal mineralization in Atlantis II Deep, and the extent of this mineralization around the deep, and to increase our understanding of the associated ores. Cores obtained by earlier research ships from the region around this deep had been found to be enriched in $\mathrm{Cu}, \mathrm{Zn}, \mathrm{Fe}, \mathrm{Mn}, \mathrm{Ag}, \mathrm{Ba}$, and $\mathrm{S}$. Questions needed to be answered concerning the origin of these elements (sediments or volcanism) and their association with hot brines also enriched in heavy metals.

Three holes drilled close to, and within, Atlantis II Deep indicated that the mineralization appears to be restricted to the area underlying the present hot brines and that the basalts beneath the heavy metal-rich muds are not potential sources of the above elements nor have they reacted in any way with these muds (reports for Sites 225, 226, 227). An unexpected result, however, was the finding that within the evaporites there are dark shales which are enriched in $\mathrm{Cu}$, $\mathrm{Zn}$, and $\mathrm{B}$ (a different facies rich in Mo and Va was also found in a similar lithology within the overlying Plio-Pleistocene sediments). This discovery (reports for Sites 225,227 , and 228) lends credence to the hypothesis that the heavy metal-rich brines are derived directly by a leaching process from local evaporitic strata and are not directly attributable to normal sea floor spreading. The heating of the brines is probably not hard to explain in such a volcanically active zone. It was noted that the top of the Atlantis II brines is at about the same level as that at which the $\mathrm{S}$ reflector crops out on the side of the deep. This observation supports the idea put forward by Swallow and Crease (1965) that brine pools can form in the Red Sea in any closed depression within which beds of halite crop out. Although the full details of the origin of the metal-rich muds and the generation of fresh hot brines have yet to be worked out, there is no doubt that work done on Leg 23 cores has brought these problems nearer to a solution (see Manheim and Siems, Chapter 29).

\section{REFERENCES}

Fisher, R. L., Bunce, E. T., Cernock, P. J., Clegg, D. C., Cronan, D. S., Damiani, V. V., Dmitriev, L., Kinsman, D. J. J., Roth, P. H., Thiede, J., and Vincent, E. S., 1972. Deep Sea Drilling Project in dodoland: Geotimes, Sept., p. 17-21.

Franchateau, J., Sclater, J. G., 1970. Comments on paper by E. Irving and W. A. Robertson, "Test for polar wandering and some possible implications": J. Geophys. Res., v. 75 (5), p. 1023-1026.

Heezen, B. C., MacGregor, I. D., Foreman, H. P., Forristal, G., Hekel, H., Hesse, R., Hoskins, R. H., Jones, E. J. W., Kaneps, A., Krasheninnikov, V. A., Okada, H., and Ruef, M. H., 1973. Diachronous deposits: a kinematic interpretation of the post-Jurassic sedimentary sequence on the Pacific plate: Nature, v. 241, p. 25-31.

Laughton, A. S., Whitmarsh, R. B., and Jones, M. T., 1970. The evolution of the Gulf of Aden: Phil. Trans. Roy. Soc. London, A, v. 267, p. 227-266.

Laughton, A. S., Berggren, W. A., Benson, R. N., Davies, T. A., Franz, U., Musich, L. F., Perch-Nielsen, K., Ruffman, A. S., van Hinte, J. E., Whitmarsh, R. B., 1972. Initial Reports of the Deep Sea Drilling Project, Volume 12: Washington (U. S. Government Printing Office).

McKenzie, D. P., Sclater, J. G., 1971. The evolution of the Indian Ocean since the Late Cretaceous: Geophys. J. Roy. Astro. Soc., v. 25, p. 437-528.

Nephrochnov Yu. P., 1961. Sediment thickness of the Arabian Sea Basin: Dokl. Akad. Nauk., Earth Sci. Sect., v. $139,(1)$, p. $177-179$.

Ryan, W. B. F., Hsu, K. J., Nesteroff, W. D., Pantot, G., Wezel, F. C., Lort, J. M., Cita, M. B., Stradner, H., Dumitrica, P., and Mayne, W., 1973 Initial Reports of the Deep Sea Drilling Project, Volume 13: Washington, (U. S. Government Printing Office).

Swallow, J. C. and Crease, J., 1965. Hot salty water at the bottom of the Red Sea: Nature, v. 205, p. 165.

Wadia, D. N., 1966. Geology of India (Third Ed.): New York (Macmillan Co.). 